\title{
Nutritive value of ghee residue incorporated bakery product
}

\author{
Rajeev Ranjan ${ }^{1}$, AK Chauhan, ${ }^{1}$ Shubhendra Singh ${ }^{1}$, Sarika Kumari ${ }^{2}$ and Ritu Prakash Dubey ${ }^{2}$
}

Received: 14 November 2019 / Accepted: 01 January 2020 / Published online: 27 February 2020

(C) Indian Dairy Association (India) 2020

\begin{abstract}
The present study entitled "Nutritive value of ghee residue incorporated bakery product" was carried out with the objectives to utilize the ghee residue for the preparation of bakery products. The products prepared were cake and muffins by utilization of ghee residue incorporated in different proportions and served as treatments $T_{1}, T_{2}, T_{3}$ and $T_{4}$ respectively and $T_{0}$ served as control. Estimation of fat, carbohydrate, protein, energy, calcium was found by AOAC (2005) methods. Sensory evaluation was carried out using the nine-point Hedonic scale. The nutritive value of the prepared products was determined using food composition tables. Data obtained were statistically analysed by using analysis of variance (ANOVA), (t) test and critical difference (CD) techniques. On the basis of findings, it was observed that in case of Cake and muffins both 60 percent refined flour and 40 percent ghee residue incorporation level scored the best with regard to colour, body and texture, taste and flavour and overall acceptability. In case of cake, the calcium $(71.35 / 100 \mathrm{~g})$, protein $(23.48 \mathrm{~g} / 100 \mathrm{~g})$ and fat $(89.96 \mathrm{~g} / 100 \mathrm{~g})$ were increased as compared to control while in muffins calcium $(68.01 \mathrm{mg} / 100 \mathrm{~g})$, protein $(21.48 \mathrm{~g} / 100 \mathrm{~g})$ and fat $(90.72 \mathrm{~g} / 100 \mathrm{~g})$ were increased as compared to control. Cost of the products on the basis of raw ingredients per $100 \mathrm{~g}$ ranged between Rs 29.00 for cake, Rs 31.00 for muffins. It was concluded that ghee residue can be incorporated in the preparation of different products for improving the nutrient content.
\end{abstract}

\footnotetext{
${ }^{1}$ Department of Dairy Science and Food Technology, Institute of Agricultural Sciences, Banaras Hindu University, Varanasi-22 1005, India

${ }^{2}$ Department of Foods and Nutrition, Ethelind School of Home Science, Sam Higginbottom Institute of Agriculture, Technology and Sciences, Allahabad - 211007 (U.P.) India

Rajeev Ranjan ( $\square)$

Department of Dairy Science and Food Technology, Institute of Agricultural Sciences, Banaras Hindu University, Varanasi-221005, U.P, India

Email-rajeevcft@gmail.com, Mobile: +91 8789251802
}

Keywords: Bakery products, Cake, Flavour, Ghee residue, Muffins, Texture

\section{Introduction}

The utilization of different bakery and confectionary products is in demand now a days due to the changes in food habit of people. Cake is one of the relished and palatable baked products which is prepared from refined flour, sugar, shortening, baking powder, egg, essence as principal ingredients and Muffins are sweet, spongy breakfast or evening snack food prepared traditionally from refined flour, sugar, oil/fat, milk and eggs (Kaur et al.2017). Preparation of plain cakes from refined flour is the conventional practice (Giami et al. 2004) however cake and muffins prepared with ghee residue have not been done so far.

India is the global leader in the production of milk and ghee residue (GR) and its production is more than $3 \mathrm{MT} /$ annum (Varma and Raju, 2008). Ghee residue is a nutritious by-product of the dairy industry, obtained during the "creamery-butter" method of ghee manufacture. It is a good source of energy as well as protein and calcium (Arumugam et al. 1989). Nutritive value of the ghee residues and its complete analysis revealed the mean value of moisture content, crude protein, crude fibre, ether extract, nitrogen free extract and total ash contents of ghee residue were 12.10, $19.86,3.49,47.12,25.63$ and 3.90 percent respectively. Fatty acid profile of ghee residue revealed that the palmitic acid registered the highest percentage (38.88) among saturated fatty acids and the oleic acid accounted for the highest percentage (25.15) among unsaturated fatty acids. Linoleic, linolenic, eicosatetraenoic and docosahexaenoic acid content of ghee residue were 2.02, 0.79, 0.36 and 0.25 per cent respectively. Amino acid profile of ghee residue revealed that the lysine and methionine, content were 0.99 and 0.61 per cent, respectively. Threonine and arginine levels are found to be at 1.44 and 0.76 per cent, respectively. The glutamic acid recorded the highest percentage (5.26), while cystine registered the lowest percentage (0.35) among amino acids in ghee residue. Thus, it could be concluded that ghee residue is a rich source of fat, protein, unsaturated fatty acids and amino acids (Ramesh et al. 2018).

An optimized process for the extraction of protein from ghee residue was suggested by (Munirathnamma et al. 2017) which 
signifies its competence to be an excellent food item for human nutrition. Ghee residue can also be a good source for overcoming protein-energy malnutrition (Dua et al. 2018). In India, the annual production of milk is 165.4 million tons as per NDDB statistics 2016-17. About $30-35 \%$ of the milk produced in India is converted in to ghee (Gandhi et al. 2013).

Ghee residue obtained at household level of ghee production is generally consumed after mixing with cooked rice or by spreading it over chapattis. However, in large ghee manufacturing and refining plants. It is thrown away as a waste product, losing a huge quantity of nutrients in terms of fat, protein and minerals. Ghee residue thus by virtue of its chemical composition, physical characteristics and long shelf life permitting its collection and centralized handling has great potential and is more emendable to exploit its utilization (Rao and Gopinath, 2001).

The aim of this study, therefore was to assess nutritional and sensory properties of ghee residue incorporated in cake and muffins with the aim of encouraging the use of these underutilized products in developing value-added products with nutraceutical potential.

\section{Materials and Methods}

Fresh cream was collected from the local market of Allahabad and Varanasi each time as per the requirement. Ghee residue was obtained by heating fresh cream. Other ingredients (refined flour, milk, salt, sugar, egg and butter etc.) were purchased from the local market of Allahabad.

\section{Preparation of Ghee residue}

Ghee residue was obtained by heating cream at $50-60^{\circ} \mathrm{C}$ for $30-40$ min or medium flame until and unless the ghee and ghee residue get separated, as given by (Aneja et al. 2002)

\section{Development of products}

Two products namely Cake and Muffins were prepared by ghee residue and other ingredients. The products were prepared by using standard recipe.

\section{Treatment and replication of the products}

Table 1 shows refined flour was replaced with ghee residue for preparation of bakery products namely cake and muffins. The whole experiment was replicated four times with four treatments.

\section{Details of Treatments}

1. Cake: -

- $\quad$ Control $\left(\mathrm{T}_{0}\right)$ : Cake was prepared with only standard ingredients without any incorporation of ghee residue.
- $\quad$ Treatment $\left(\mathrm{T}_{1}\right)$ : Cake was prepared with refined flour and ghee residue in a ratio of 90:10.

- $\quad$ Treatment $\left(\mathrm{T}_{2}\right)$ : Cake was prepared with refined flour and ghee residue in a ratio of 80:20.

- $\quad$ Treatment $\left(\mathrm{T}_{3}\right)$ : Cake was prepared with refined flour and ghee residue in a ratio of 70:30.

- $\quad$ Treatment $\left(\mathrm{T}_{4}\right)$ : Cake was prepared with refined flour and ghee residue in a ratio of 60:40.

2. Muffins: -

- $\quad$ Control $\left(\mathrm{T}_{0}\right)$ : Muffin was prepared with only standard ingredients with any incorporation of ghee residue.

- $\quad$ Treatment $\left(\mathrm{T}_{1}\right)$ : Muffin was prepared with refined flour and ghee residue in a ratio of 90:10.

- $\quad$ Treatment $\left(\mathrm{T}_{2}\right)$ : Muffin was prepared with refined flour and ghee residue in a ratio of 80:20.

- $\quad$ Treatment $\left(\mathrm{T}_{3}\right)$ : Muffin was prepared with refined flour and ghee residue in a ratio of 70:30.

- $\quad$ Treatment $\left(\mathrm{T}_{4}\right)$ : Muffin was prepared with refined flour and ghee residue in a ratio of 60:40.

\section{Sensory evaluation of developed products}

The panel of judges assessed the coded cake and muffins samples at random, according to the methodology described by (Meilgaard et al.1999). Sensory evaluation of samples was carried out with a 10-member panel (ages 22 to 45 year) who were scientists, students and technical staff of Department of Food \& Nutrition, Ethelind School of Home Science SHUATS Allahabad. The panellists had a good knowledge on the sensory evaluation of dairy products and participated previously in such evaluations. Sensory evaluation of the samples was carried out in the sensory evaluation room under appropriate fluorescent lighting. Each panellist was asked to taste the samples and rate the sensory parameters on a 9-point hedonic scale. According to the 9-point structured hedonic scale, the acceptance test was carried out for the attributes of colour and appearance, body and texture, flavour and overall acceptability. For all the attributes, 9-point scale was defined as that the highest value indicates the highest degree of preference.

\section{Chemical analysis of developed products}

Products prepared were chemically analysed by the standardized procedure of AOAC (2005). The proximate components viz., moisture, ash, carbohydrate, fat, protein and calcium were determined by using standard procedure prescribed by AOAC (2005) each sample were replicated three times.

\section{Cost of developed products}

The prevailing prices of the ingredients used in the preparation of the products were used to calculate their actual cost.

\section{Statistical analysis}

The data obtained from sensory evaluation were statistically analysed by using analysis of variance technique (one-way 
classification). Significant difference between the treatments was determined by using $\mathrm{CD}$ (critical difference) test.

\section{Packaging of Developed Product}

Food grade 3-ply laminated film of polyethylene/aluminium foil/ polyethylene (PE/Al foil/PE) of thickness $80 \mu$ procured from local market of Varanasi, U.P were used as packaging material for packaging of ghee residue incorporated cake and muffins. Each packet weight about $200 \mathrm{gm}$.

\section{Results and Discussion}

\section{Optimization of basic formulation for the preparation of ghee residue incorporated cake and muffins}

The basic formulation of the cake and muffins was optimised for the different levels of ghee residue, Other ingredients (refined flour, milk, salt, sugar, egg and butter etc.) For this purpose, different proportions of ghee residue and refined flour viz. 10:90, 20:80, 30:70 and 40:60 were used for preparation of cake and muffins keeping the fixed level of other ingredients (as per the standard) to optimize the levels of ghee residue and refined flour. The 0:100 combination served as control. The products were judged on the basis of various sensory attributes. The results are presented in table 3 and 5 . Results showed that with increase in the levels of ghee residue a non-significant $(\mathrm{P}>0.05)$ change was observed up to 40:60 level thereafter, a significant $(\mathrm{P}<0.05)$ decrease was observed. This could be due to the brown colour of the ghee residue and so could be incorporated up to $40 \%$ level. This is in accordance with the study of Borawake and Bhosale (1996), where it was observed that increasing levels of replacement of fat with GR decreased the colour and appearance scores in nankhatai type cookies and sponge cakes. The scores for flavour increased non-significantly $(\mathrm{P}>0.05)$ with the increase in the content of ghee residue. This is probably because of the high flavour potential of GR due to the presence of high FFA, carbonyls and lactones (Galhotra and Wadhwa 1991a and 1991b). Overall acceptability of cake and muffins containing Ghee residue: refined flour up to 40:60 level had comparable scores. The overall acceptability scores decreased as the level of replacement increased but the difference was statistically not significant. Similar results were seen by Subbulakshmi et al. (1990), where the mean score obtained for the control was 2.16 which increased to 2.34 and 2.40 in 50 and 100 percent ghee residue substituted biscuits and cakes respectively on a three point scale. Based on above observations, $40 \%$ ghee residue and $60 \%$ refined flour proportion was selected for further studies.

\section{Composition of ghee residue}

It is evident from the results (Table 2) that the ghee residue contained $893.50 \pm 3.95 \mathrm{kcal}$ energy, $50.25 \pm 0.33 \mathrm{~g}$ fat, $25.07 \pm 0.46 \mathrm{~g}$ protein, $13.28 \pm 0.08 \%$ moisture, $8.24 \pm 0.43 \mathrm{~g}$ ash, $0.91 \pm 0.03 \mathrm{mg}$ calcium and trace amount of total carbohydrate and the data showed non-significant $(\mathrm{P}>0.05)$ change. The Comparative values of ghee residue per $100 \mathrm{~g}$ as given by Arumugam et al. (1989) are moisture 13.4 , protein $25.8 \mathrm{~g}$, fat $50.8 \mathrm{~g}$, energy $900 \mathrm{kcal}$, calcium $0.88 \mathrm{mg}$

\section{Sensory characteristics of cake}

The table 3 shows that the mean sensory scores of cake in relation to colour which indicates that $\mathrm{T}_{4}(8.25 \pm 0.19)$ had the highest score followed by $\mathrm{T}_{3}(8.15 \pm 0.20), \mathrm{T}_{2}(7.8 \pm 0.22), \mathrm{T}_{1}(7.35 \pm 0.16)$ and $\mathrm{T}_{0}$ $(6.85 \pm 0.15)$ respectively. Scoring shows that the treatment $\mathrm{T}_{4}$ was liked very much while $\mathrm{T}_{3}, \mathrm{~T}_{2} \mathrm{~T}_{1}$ and $\mathrm{T}_{0}$ were moderately liked by the panel of judges. The body and texture of cake clearly

Table 1 Details of control and treatment combinations

\begin{tabular}{|c|c|c|c|c|c|c|c|c|c|c|c|}
\hline \multicolumn{7}{|c|}{ Treatment products } & \multicolumn{4}{|c|}{ Treatments $\%$} & \multirow[b]{2}{*}{ Replications } \\
\hline & $\overline{\mathrm{T}_{0}}$ & & $\mathrm{~T}_{1}$ & & $\mathrm{~T}_{2}$ & & $T_{3}$ & & $\mathrm{~T}_{4}$ & & \\
\hline & R.F & GR & R.F & $\overline{G R}$ & R.F & $\overline{G R}$ & $\overrightarrow{\text { R.F }}$ & $\overline{\mathrm{GR}}$ & R.F & $\overline{\mathrm{GR}}$ & \\
\hline Cake & 100 & - & 90 & 10 & 80 & 20 & 70 & 30 & 60 & 40 & 4 \\
\hline
\end{tabular}

R.F: Refined Flour, G.R: Ghee Residue

Table 2 Nutrient composition of ghee residue per $100 \mathrm{~g}$

\begin{tabular}{lc}
\hline Nutrients & Nutritive Value \\
\hline Energy kcal/100g & $893.50 \pm 3.95$ \\
fat g/100g & $50.25 \pm 0.33$ \\
Protein $\mathrm{g} / 100 \mathrm{~g}$ & $25.07 \pm 0.46$ \\
Moisture $\%$ & $13.28 \pm 0.08$ \\
Ash $\mathrm{g} / 100 \mathrm{~g}$ & $8.24 \pm 0.43$ \\
Calcium mg/100g & $0.91 \pm 0.03$ \\
Total carbohydrate g/100g & Traces \\
\hline
\end{tabular}


indicates that the treatment $\mathrm{T}_{4}(8.6 \pm 0.1)$ had the highest score for the body and texture of Cake followed by $\mathrm{T}_{3}(8.3 \pm 0.11), \mathrm{T}_{2}$ $(7.8 \pm 0.22), \mathrm{T}_{1}(7.5 \pm 0.18)$ and $\mathrm{T}_{0}(6.85 \pm 0.11)$ respectively. The effect of ghee residue on the taste \& flavor of cake indicates that treatment $\mathrm{T}_{2}(8.65 \pm 0.25)$ held the maximum scores as compared to control $\mathrm{T}_{0}(7.6 \pm 0.37), \mathrm{T}_{1}(7.7 \pm 0.33), \mathrm{T}_{3}(8.6 \pm 0.37)$ and $\mathrm{T}_{4}$ $(8.4 \pm 0.46)$. The mean scores of cake in relation to overall acceptability indicates that the treatment $\mathrm{T}_{4}(8.43 \pm 0.08)$ scored maximum followed by treatment $\mathrm{T}_{3}(8.36 \pm 0.10), \mathrm{T}_{2}(7.59 \pm 0.16), \mathrm{T}_{1}$ $(7.51 \pm 0.078)$ and $\mathrm{T}_{0}(7.09 \pm 0,09)$.

\section{Nutrients content in control and treated samples of cake}

Table 4 shows that highest protein, calcium and fat was found in $\mathrm{T}_{4}$ as $23.48 \pm 0.21 \mathrm{~g}, 71.35 \pm 0.64 \mathrm{mg}$ and $89.96 \pm 0.81 \mathrm{~g}$ respectively followed by $\mathrm{T}_{3}, \mathrm{~T}_{2}, \mathrm{~T}_{1}$ and $\mathrm{T}_{0}$. Energy $(1560.2 \pm 13.99 \mathrm{kcal})$ and carbohydrate $(173.3 \pm 1.55 \mathrm{~g})$ content was found to be highest in $\mathrm{T}_{0}$. Energy and Carbohydrate content decreased as the incorporation of ghee residue increased. Therefore, it can be concluded that with increase in amount of ghee residue in Cake the percentage of protein, fat and calcium increased. Energy and Carbohydrate content decreased by increasing the level of Ghee residue since refined flour contain $356.64 \mathrm{kcal}$ energy per $100 \mathrm{~g}$ (Dutta et al. 2018) so with the decrease in refined flour content the energy value of cake decreases significantly.

\section{Sensory characteristics of Muffins}

The data illustrated in the Table 5, indicates the effect of ghee residue on the colour and appearance of muffins indicates that the treatment $\mathrm{T}_{4}(8.55 \pm 0.08)$ got the highest sensory score for the colour of muffins followed by $\mathrm{T}_{3}(7.8 \pm 0.07), \mathrm{T}_{2}(7.55 \pm 0.10)$, $\mathrm{T}_{1}(6.85 \pm 0.29)$ and $\mathrm{T}_{0}(6.15 \pm 0.23)$ It is concluded that the concentration of ghee residue influences the appearance of products. The mean sensory score to the effect of addition of ghee residue to the body and texture of muffins shows that the treatment $\mathrm{T}_{4}$ scored the maximum marks of $(8.35 \pm 0.22)$ followed by $\mathrm{T}_{2}(8 \pm 0.15) \mathrm{T}_{3}(7.85 \pm 0.17), \mathrm{T}_{1}(7.25 \pm 0.24)$ and $\mathrm{T}_{0}(6.2 \pm 0.27)$ respectively. Therefore, it is concluded that the treatment 4 were liked moderately while $\mathrm{T}_{2}$ was liked very much by the panel of

Table 3 The average sensory scores of different parameters in control and treated sample of 'Cake'

\begin{tabular}{lllcc}
\hline Treatments & Color and appearance & Body and Texture & Taste and flavor & Overall acceptability \\
\hline $\mathrm{T}_{0}$ (Control) & $6.85 \pm 0.15$ & $6.85 \pm 0.11$ & $7.6 \pm 0.37$ & $7.09 \pm 0.09$ \\
$\mathrm{~T}_{1}$ & $7.35 \pm 0.16$ & $7.5 \pm 0.18$ & $7.7 \pm 0.33$ & $7.51 \pm 0.08$ \\
$\mathrm{~T}_{2}$ & $7.8 \pm 0.22$ & $7.8 \pm 0.22$ & $8.65 \pm 0.25$ & $7.59 \pm 0.16$ \\
$\mathrm{~T}_{3}$ & $8.15 \pm 0.20$ & $8.3 \pm 0.11$ & $8.6 \pm 0.37$ & $8.36 \pm 0.10$ \\
$\mathrm{~T}_{4}$ & $8.25 \pm 0.19$ & $8.6 \pm 0.1$ & $8.4 \pm 0.46$ & $8.43 \pm 0.08$ \\
$\mathrm{~F}-$ calculated & $17.74(\mathrm{~S})$ & $32.5(\mathrm{~S})$ & $0.744(\mathrm{NS})$ & $77.2(\mathrm{~S})$ \\
C.D & 0.19 & 0.42 & - & 0.10 \\
\hline
\end{tabular}

$\mathrm{S}=$ Significant,$\quad \quad \quad \pm=\mathrm{S} . \mathrm{E} \quad \mathrm{NS}=$ Non- Significant

Table 4 Average nutrients content in control and treated samples of "cake"

\begin{tabular}{lllllc}
\hline \multirow{2}{*}{$\begin{array}{l}\text { Nutrients } \\
\text { (per 100g) }\end{array}$} & Control $\mathrm{T}_{0}$ & \multicolumn{3}{c}{ Treatments } \\
\cline { 3 - 6 } & & \multicolumn{1}{c}{$\mathrm{T}_{1}$} & \multicolumn{1}{c}{$\mathrm{T}_{2}$} & $\mathrm{~T}_{3}$ & $\mathrm{~T}_{4}$ \\
\hline Energy(kcal) & $1560.2 \pm 13.99$ & $1502.5 \pm 13.48$ & $1445 \pm 12.96$ & $1387.5 \pm 12.44$ & $1329.6 \pm 11.93$ \\
Carbohydrate(g) & $173.3 \pm 1.55$ & $155.97 \pm 1.40$ & $138.64 \pm 1.24$ & $121.31 \pm 1.08$ & $103.38 \pm 0.93$ \\
Fat $(\mathrm{g})$ & $88.4 \pm 0.79$ & $88.29 \pm 0.79$ & $88.18 \pm 0.78$ & $89.07 \pm 0.80$ & $89.96 \pm 0.81$ \\
Calcium(mg) & $65 \pm 0.58$ & $66.58 \pm 0.59$ & $68.17 \pm 0.61$ & $69.76 \pm 0.58$ & $71.35 \pm 0.64$ \\
Protein(g) & $17.6 \pm 0.16$ & $19.07 \pm 0.17$ & $20.54 \pm 0.18$ & $22.01 \pm 0.19$ & $23.48 \pm 0.21$ \\
\hline
\end{tabular}

Table 5 Average sensory scores of different parameters in control and treated sample of 'Muffins'

\begin{tabular}{|c|c|c|c|c|}
\hline Treatments & $\begin{array}{l}\text { Color and } \\
\text { appearance }\end{array}$ & $\begin{array}{l}\text { Body and } \\
\text { Texture }\end{array}$ & Taste and flavor & $\begin{array}{c}\text { Overall } \\
\text { acceptability }\end{array}$ \\
\hline$\overline{\mathrm{T}_{0}(\text { Control })}$ & $6.15 \pm 0.23$ & $6.2 \pm 0.27$ & $6.5 \pm 0.16$ & $6.2 \pm 0.53$ \\
\hline $\mathrm{T}_{1}$ & $6.85 \pm 0.29$ & $7.25 \pm 0.24$ & $7.2 \pm 0.12$ & $7 \pm 0.16$ \\
\hline $\mathrm{T}_{2}$ & $7.55 \pm 0.10$ & $8 \pm 0.15$ & $7.7 \pm 0.20$ & $7.7 \pm 0.31$ \\
\hline $\mathrm{T}_{3}^{2}$ & $7.8 \pm 0.07$ & $7.85 \pm 0.17$ & $8 \pm 0.21$ & $7.8 \pm 0.08$ \\
\hline $\mathrm{T}_{4}$ & $8.55 \pm 0.08$ & $8.35 \pm 0.22$ & $8.2 \pm 0.23$ & $8.4 \pm 0.17$ \\
\hline
\end{tabular}


Table 6 Average nutrients content in control and treated samples of "Muffins"

\begin{tabular}{lllllc}
\hline $\begin{array}{l}\text { Nutrients } \\
\text { (per 100g) }\end{array}$ & Control $\quad \mathrm{T}_{0}$ & \multicolumn{1}{c}{$\mathrm{T}_{1}$} & \multicolumn{1}{c}{ Treatments } & \multicolumn{1}{c}{$\mathrm{T}_{3}$} & $\mathrm{~T}_{4}$ \\
\hline Energy(kcal) & $1533.22 \pm 13.75$ & $1495.3 \pm 13.41$ & $1438.42 \pm 12.90$ & $1379.15 \pm 12.37$ & $1324.72 \pm 11.88$ \\
Carbohydrate(g) & $175.5 \pm 1.57$ & $158.17 \pm 1.42$ & $140.84 \pm 1.26$ & $123.51 \pm 1.11$ & $105.58 \pm 0.95$ \\
Fat $(\mathrm{g})$ & $84.18 \pm 0.75$. & $87.29 \pm 0.78$ & $88.18 \pm 0.79$ & $89.07 \pm 0.80$ & $90.72 \pm 0.81$ \\
Calcium(mg) & $62 \pm 0.55$ & $64.67 \pm 0.58$ & $65.03 \pm 0.58$ & $66.12 \pm 0.59$ & $68.01 \pm 0.61$ \\
Protein(g) & $18.4 \pm 0.16$ & $19.25 \pm 0.17$ & $20.36 \pm 0.18$ & $20.87 \pm 0.18$ & $21.48 \pm 0.19$ \\
\hline
\end{tabular}

Table 7 Cost of "Cake" per $100 \mathrm{~g}$ of raw ingredients

\begin{tabular}{|c|c|c|c|c|c|c|c|c|c|c|}
\hline Treatment & $\mathrm{T}_{0}$ & & $\mathrm{~T}_{1}$ & & $\mathrm{~T}_{2}$ & & $\mathrm{~T}_{3}$ & & $\mathrm{~T}_{4}$ & \\
\hline Ingredients & $\begin{array}{l}\text { Quantity } \\
\text { (g./ml.) }\end{array}$ & $\begin{array}{l}\text { Cost } \\
\text { (Rs.) }\end{array}$ & $\begin{array}{l}\text { Quantity } \\
\text { (g./ml.) }\end{array}$ & $\begin{array}{l}\text { Cost } \\
\text { (Rs.) }\end{array}$ & $\begin{array}{l}\text { Quantity } \\
\text { (g./ml.) }\end{array}$ & $\begin{array}{l}\text { Cost } \\
\text { (Rs.) }\end{array}$ & $\begin{array}{l}\text { Quantity } \\
\text { (g./ml.) }\end{array}$ & $\begin{array}{l}\text { Cost } \\
\text { (Rs.) }\end{array}$ & $\begin{array}{l}\text { Quantity } \\
\text { (g./ml.) }\end{array}$ & $\begin{array}{l}\text { Cost } \\
\text { (Rs.) }\end{array}$ \\
\hline Ghee Residue (200/kg.) & - & - & 10 & 2 & 20 & 4 & 30 & 6 & 40 & 8 \\
\hline Sugar (40/kg.) & 100 & 4 & 90 & 3.6 & 80 & 3.2 & 70 & 2.8 & 60 & 2.4 \\
\hline Butter $(20 / 100 g)$ & 100 & 20 & 90 & 18 & 80 & 16 & 70 & 14 & 60 & 12 \\
\hline
\end{tabular}

Table 8 Cost of "Muffins" per $100 \mathrm{~g}$ of raw ingredients

\begin{tabular}{|c|c|c|c|c|c|c|c|c|c|c|}
\hline Treatment & $\mathrm{T}_{0}$ & & $\mathrm{~T}_{1}$ & & $\mathrm{~T}_{2}$ & & $\mathrm{~T}_{3}$ & & $\mathrm{~T}_{4}$ & \\
\hline Ingredients & $\begin{array}{l}\text { Quantity } \\
\text { (g./ml.) }\end{array}$ & $\begin{array}{l}\text { Cost } \\
\text { (Rs.) }\end{array}$ & $\begin{array}{l}\text { Quantity } \\
(\mathrm{g} / \mathrm{ml})\end{array}$ & $\begin{array}{l}\text { Cost } \\
\text { (Rs.) }\end{array}$ & $\begin{array}{l}\text { Quantity } \\
\text { (g./ml.) }\end{array}$ & $\begin{array}{l}\text { Cost } \\
\text { (Rs.) }\end{array}$ & $\begin{array}{l}\text { Quantity } \\
\text { (g./ml.) }\end{array}$ & $\begin{array}{l}\text { Cost } \\
\text { (Rs.) }\end{array}$ & $\begin{array}{l}\text { Quantity } \\
\text { (g./ml.) }\end{array}$ & $\begin{array}{l}\text { Cost } \\
\text { (Rs.) }\end{array}$ \\
\hline Ghee Residue (200/kg.) & - & - & 10 & 2 & 20 & 4 & 30 & 6 & 40 & 8 \\
\hline Sugar (40/kg.) & 100 & 4 & 90 & 3.6 & 80 & 3.2 & 70 & 2.8 & 60 & 2.4 \\
\hline Butter (20/100g) & 100 & 20 & 90 & 18 & 80 & 16 & 70 & 14 & 60 & 12 \\
\hline $\operatorname{Egg}(1 / p c)$ & $1 \mathrm{pc}$ & 5 & $1 \mathrm{pc}$ & 5 & $1 \mathrm{pc}$ & 5 & $1 \mathrm{pc}$ & 5 & $1 \mathrm{pc}$ & 5 \\
\hline Total & & 33.20 & & 32.58 & & 31.96 & & 31.34 & & 30.72 \\
\hline
\end{tabular}

judges. The sensory mean scores of muffins in relation to taste and flavor indicates that $\mathrm{T}_{4}(8.2 \pm 0.23)$ had the highest score followed by $\mathrm{T}_{3}(8 \pm 0.21) \mathrm{T}_{2}(7.7 \pm 0.20), \mathrm{T}_{1}(7.2 \pm 0.12)$ and $\mathrm{T}_{0}(6.5 \pm 0.16)$ respectively. The mean sensory scores of Muffins in relation to overall acceptability indicates that $\mathrm{T}_{4}(8.4 \pm 0.17)$ had the highest score followed by $\mathrm{T}_{3}(7.8 \pm 0.08) \mathrm{T}_{2}(7.7 \pm 0.31) \mathrm{T}_{1}(7 \pm 0.16)$ and $\mathrm{T}_{0}$ $(6.2 \pm 0.53)$ respectively.

\section{Nutrients content in control and treated samples of Muffins}

The Table 6, indicates that the nutritive value of muffins with and without utilization of ghee residue at different levels i.e. 10 percent, 20 percent, 30 percent and 40 percent of $\mathrm{T}_{1}, \mathrm{~T}_{2}, \mathrm{~T}_{3}$ and $\mathrm{T}_{4}$ respectively. Result revealed that highest protein, calcium and fat was found in $\mathrm{T}_{4}$ in the order of $21.48 \pm 0.19 \mathrm{~g}, 68.01 \pm 0.61 \mathrm{mg}$, and $90.72 \pm 0.8 \mathrm{~g}$ respectively followed by $\mathrm{T}_{3}, \mathrm{~T}_{2}, \mathrm{~T}_{1}$ and $\mathrm{T}_{0}$. Energy $(1533.22 \pm 13.75 \mathrm{kcal})$ and carbohydrate $(175.5 \pm 1.57 \mathrm{~g})$ content was found to be highest in $\mathrm{T}_{0}$. Energy and Carbohydrate content decreased by increasing the level of Ghee residue.

\section{Cost of developed products (per 100g)}

Table 7 shows that total cost of cake for $\mathrm{T}_{0}$ was $31.20 \mathrm{Rs} / 100 \mathrm{~g}, \mathrm{~T}_{1}$ was $30.58 \mathrm{Rs} / 100 \mathrm{~g}, \mathrm{~T}_{2}$ was $29.96 \mathrm{Rs} / 100 \mathrm{~g}, \mathrm{~T}_{3}$ was $29.34 \mathrm{Rs} / 100 \mathrm{~g}$ and $\mathrm{T}_{4}$ was $28.72 \mathrm{Rs} / 100 \mathrm{~g}$. It is therefore, concluded that the treatment $\mathrm{T}_{0}$ has highest cost followed by $\mathrm{T}_{1} \mathrm{~T}_{2} \mathrm{~T}_{3}$ and $\mathrm{T}_{4}$. The cost of the developed food product is decrease due to incorporation of ghee residue at different levels and table 8 shows that total cost muffins for $\mathrm{T}_{0}$ was $33.20 \mathrm{Rs} / 100 \mathrm{~g}$, $\mathrm{T}_{1}$ was $32.58 \mathrm{Rs} /$ $100 \mathrm{~g}, \mathrm{~T}_{2}$ was $31.96 \mathrm{Rs} / 100 \mathrm{~g}, \mathrm{~T}_{3}$ was $31.34 \mathrm{Rs} / 100 \mathrm{~g}$ and $\mathrm{T}_{4}$ was $30.72 \mathrm{Rs} / 100 \mathrm{~g}$. It is therefore, concluded that the treatment $\mathrm{T}_{0}$ has highest cost followed by $T_{1} T_{2} T_{3}$ and $T_{4}$. The cost of the developed food product is decrease due to incorporation of ghee residue at different levels.

\section{Conclusions}

It is concluded that ghee residue can suitably be incorporated in prepared cake and muffins bakery products. The product was 
accepted with regard to sensory characteristics. Both the products prepared with treatment $\mathrm{T}_{4}$ using 40 percent ghee residue and 60 percent refined wheat flour scored the best in term of colour and appearance, body and texture, taste and flavour and overall acceptability. Nutritional composition of the prepared bakery products regarding fat, protein and calcium were increased as the level of incorporation of ghee residue increased.

\section{References}

AOAC. 2005. Approved methods of the American Association of Cereal Chemists.10th edition, AACC, St Paul, Minnesota

Arumugam MP, Vedhanayagam K, Doraisamy KA, Narahari D (1989) Chemical composition and nutritive value of ghee residue for chickens. Anim Feed Scie Technol 26: 119-128

Borawake KA, Bhosale DN (1996) Utilisation of ghee residue in preparation of nankatai type cookies and sponge cakes. Indian J Dairy Sci 49: 114-119

Aneja RP, Mathur BN, Chandan RC, Baneerjee AK (2002) Fat-rich products. In: Technology of Indian milk products. A Dairy India Publication, Delhi, India, pp 190-196

Dua S, Kumar S, Kaur S, Ganai AW, Khursheed I (2018) Chemical and sensory attributes of ghee residue burfi supplemented with corn flour. J Pharmacognosy Phytochem 7: 3818-3822

Dutta A, Tilara S, Jantwal C, Khan R (2018) Quality evaluation of differently processed wheat flours. Asian J Dairy Food Res 37: 6164

Galhotra KK, Wadhwa BK(1991a)Flavour potential of Gheeresidue Part I: Free Fatty acids and total carbonyls level. Indian J Dairy Sci 44 : 565-567
Galhotra KK, Wadhwa BK(1991b) Flavour potential of Gheeresidue Part - II: Lactones level. Indian J Dairy Sci 44: 568-572

Gandhi K, Arora S, Pawar N, Kumar N (2013) Effect of vidarikhand (extracts) or oxidative stability of ghee: a comparative study. Research and reviews: J Dairy Sci Technol2: 1-11

Giami SY (2004) Comparison of bread making properties of composite flour from kernels of roasted and boiled African bread fruit (Treculia Africana decne) seeds. J Mat Res 1: 16-25

Kaur K, Singh G, Singh N (2017) Development and evaluation of gluten free muffins utilizing green banana flour. Bioved 28: 359-365

Meilgaard MC, Carr BT, Civille GV (1999) Sensory evaluation techniques. CRC press.

Munirathnamma V, Gupta VK, Meena GS (2017) Effect of different extraction processes on the recovery of ghee residue proteins. Indian J Anim Sci 87: 366-372

Ramesh P, Valavan SE, Gnanaraj PT, Omprakash AV, Varun A (2018) Nutrient composition of ghee residue. J Pharmacognosy Phytochem 7: 3316-3319

Rao HGR, Gopinath S (2001) Importance of ghee residue and its utilization Indian Dairyman 53: 15-19

Subbulakshmi G, Periwal S, Rani PJ (1990) Studies on shelf life and utilisation of ghee residue. J Food Sci Technol 27: 165-166

Varma BB, Narender Raju P (2008) Ghee residue: Processing, properties and utilization. course compendium on "Technological advances in the utilization of dairy by-products". Centre of Advanced Studies in Dairy Technology, NDRI, Karnal. p, 176-183 